"Can effective tax rates mediate the effect of profitability and debts on income smoothing?"

\begin{tabular}{|c|c|}
\hline AUTHORS & Enni Savitri E https://orcid.org/0000-0002-3514-5993 \\
\hline ARTICLE INFO & $\begin{array}{l}\text { Enni Savitri (2019). Can effective tax rates mediate the effect of profitability and } \\
\text { debts on income smoothing?. Problems and Perspectives in Management, 17(3), } \\
\text { 89-100. doi:10.21511/ppm.17(3).2019.07 }\end{array}$ \\
\hline DOI & http://dx.doi.org/10.21511/ppm.17(3).2019.07 \\
\hline RELEASED ON & Monday, 29 July 2019 \\
\hline RECEIVED ON & Tuesday, 19 February 2019 \\
\hline \multirow[t]{2}{*}{ ACCEPTED ON } & Friday, 22 March 2019 \\
\hline & $(c c)$ EY \\
\hline LICENSE & $\begin{array}{l}\text { This work is licensed under a Creative Commons Attribution } 4.0 \text { International } \\
\text { License }\end{array}$ \\
\hline JOURNAL & "Problems and Perspectives in Management" \\
\hline ISSN PRINT & $1727-7051$ \\
\hline ISSN ONLINE & $1810-5467$ \\
\hline PUBLISHER & LLC "Consulting Publishing Company "Business Perspectives" \\
\hline FOUNDER & LLC "Consulting Publishing Company "Business Perspectives" \\
\hline & 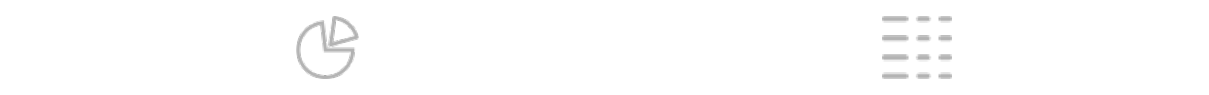 \\
\hline NUMBER OF REFERENCES & NUMBER OF FIGURES \\
\hline 36 & 5 \\
\hline
\end{tabular}

(C) The author(s) 2023. This publication is an open access article. 


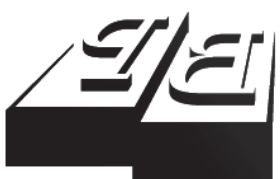

BUSINESS PERSPECTIVES

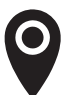

LLC "CPC "Business Perspectives" Hryhorii Skovoroda lane, 10, Sumy, 40022, Ukraine

www.businessperspectives.org

Received on: $19^{\text {th }}$ of February, 2019 Accepted on: 22nd of March, 2019

(C) Enni Savitri, 2019

Enni Savitri, Dr., Faculty of Economics and Business, Universitas Riau, Indonesia.

\section{CAN EFFECTIVE TAX RATES MEDIATE THE EFFECT OF PROFITABILITY AND DEBTS ON INCOME SMOOTHING?}

\begin{abstract}
The management of the company must be capable of providing better financial information for the users of the financial report. The users of the financial report notice the performance of the management from the financial report. The financial report provides information related to financial positions, performance, as well as the changes in financial positions that are beneficial for decision-making. Income smoothing is generally conducted by the company to see the company's capability and show the investors or investor candidates that the company is in stable condition in generating profits for the increase of share value and giving dividends, so that the investors are attracted to invest in that company. Income smoothing has been a debatable topic, especially among practitioners and academicians. This study analyzes both the direct and indirect effects of profitability and corporate debt on income smoothing. It also examines whether tax rates mediates the effects of profitability and debt on income smoothing. The sample consists of 12 property and real estate companies on the Indonesia Stock Exchange in 2013-2017. The sample was selected using purposive sampling technique. Data were analyzed using Partial Least Squares (PLS) analysis tool with the WarpPls application. The results show that profitability and debt, as well as effective tax rates, affect income smoothing. The effective tax rates can mediate the relationship between profitability and debt and income smoothing.
\end{abstract}

Keywords

JEL Classification

profitability, debt, income smoothing, effective tax rates and financial report

G32, H25

\section{INTRODUCTION}

The management of a company is obliged to provide financial information for users of financial statements. Looking at the financial statements, the users could, then, assess the performance of its managers and the company. The financial statements are a means of information on management's accountability for the use of company resources. The information on earnings in financial statements is very useful for management to make a decision. However, the existence of profit information encourages management to perform dysfunctional behavior. Maximizing profits by utilizing the flexibility of accounting standards are used by companies is one form of dysfunctional behavior. This dysfunctional behavior arises due to the existence of asymmetrical information between the parties concerned. As a result, companies need to involve with earnings management. One of the ways to do this is by engaging with income smoothing practices.

Income smoothing is performed by companies to show the investors their ability to generate profits and stable condition (We Fu et al., 2002; Acharya \& Lambrecht, 2015). By having this, the existing investors will keep their investment and potential investors will be interested to 
place their investment in this company. Income smoothing is also a motivation for management to maintain its position as a director and to get huge rewards. By making income smoothing, the management can manage the company so that the condition of the company is stable in generating profits (Ghaemi et al., 2003; Li \& Richie, 2016). The act of income smoothing in financial statements causes the disclosure of earnings information to be misleading (Ball et al., 2000). Income smoothing can also cause errors in decision-making by parties who have an interest in the company such as shareholders and creditors. The practice of income smoothing will not occur if the expected profit is not too different from the actual profit (Banam \& Mehzaren, 2016).

The income smoothing case occurred in several companies on the Indonesia Stock Exchange. The companies have inflated their profits. Syahrul (2002) states that it was known after a re-audit of their financial statements as of December 31, 2001, which reported a net profit of around IDR 132 billion. After a re-audit, however, it turned out that the companies' profits were only IDR 99.56 billion, lower by IDR 32.6 billion or $24.7 \%$ of the reported initial profits. The differences in retained earnings were due to errors. First, it was because of basic misstatements relating to inventory prices, which were marked up and used as a basis for valuation of inventory; the second mistake was in presentation relating to sales by the double-recording of the sales (Syahrul, 2002). In the case of PT Agis, based on the inspection result of Bapepam (The Indonesian Regulatory Authority for the Indonesian Capital Market, 2007), it is proven that it has given information that materially was not largely related to the income of two acquired companies that are PT. Akira Indonesia (inc) and PT. TT Indonesia (inc.), the income of the two companies is IDR 800 billion, but based on the Financial Report of the two companies to be acquired as of March 31,2007 , the total income was only around IDR 466.8 billion. AGIS also committed violations related to the AGIS Financial Report, which was a consolidation of its subsidiaries, where one of them is PT AGIS Eletronic. In the AGIS Consolidated Profit and Loss Report, it is revealed that the net other income of IDR 29.4 billion was disclosed, which originated from the AGIS Electronics Financial Report as a subsidiary of AGIS, which was not supported by competent evidence and application of accounting principles errors. Therefore, other income in the Electronic AGIS Financial Report is not reasonable, which results in the AGIS Consolidated Financial Report (Tempo, 2007). The phenomenon of income smoothing has been performed by many companies for a long time, but a debate remains among practitioners and academicians about whether or not the action is ethical. Practitioners consider income smoothing as cheating, while academic scholars argue that income smoothing cannot be categorized as a fraud. However, they agree that income smoothing is an attempt to stabilize profits by using accounting methods and procedures that are generally accepted and recognized. Auditors can scrutinize the company's financial ratios to assess if there is a practice of income smoothing (Jacksonh \& Pitman, 2001).

Financial ratios are used to analyze financial statements and measure company's performance. Return on equity (ROE) describes the net income obtained from the total equity of a company. In general, companies with lower ROE have a tendency to practice income smoothing compared to companies with higher ROE (Salehi, 2011). This is because companies with low profitability will be required to manage company profits so that investors do not move to other companies. For this reason, management needs to make earnings look more stable by making income smoothing. The effect of ROE on the practice of income smoothing was described in the study by Li-Jung and Chien-Wen (2007). However, some other studies such as Habib (2012), Acharya and Lambrecht (2015), and Fengju et al. (2013) showed different results by stating that ROE does not effect on income smoothing.

Debt to total assets ratio (DAR) describes the amount of debt used to finance total assets. The high value of debt to total assets indicates that most of the company's assets are financed by debt. The high DAR leads management to do income smoothing. This is done to get a relatively good bargaining position in the negotiation or rescheduling of debts from creditors (Mashayekhi, 2005). The management decides to do income smoothing practices so that the company's performance looks good. With such a good performance, it is expected that creditors will continue to have trust in the company, continue to disburse 
funds and obtain convenience in the process of repaying the debt. This argument is the result of research by Salehi (2011), Habib (2012). However, some other studies such as Fengju et al. (2013), Frey (2018) show a different result indicating that debt to total assets ratio (DAR) does not influence income smoothing.

Habib (2012) states that the occurrence of income smoothing practices is also influenced by conflicts of interest between internal parties (management) and external parties (shareholders, creditors, and government). The management prefers to pay low taxes, while the government wants to collect taxes according to the tax rate. Effective tax rates are used to measure the impact of changes in tax policy on corporate tax expense. The percentage of companies paying taxes on commercial profits obtained by the company can be found out by using an effective tax rate. With this effective tax rate, companies can see the real number of taxes paid by the companies if the paying taxes are greater or less than the rates set based on the company's commercial profit before tax. The effective company tax rate is an important measure of the tax burden for policymakers for certain types of businesses and in providing incentives to taxpayers.

This study employs effective tax rates as mediation. This is because effective tax rates are one of the biggest factors that encourage management to do income smoothing. Scott (2000) states that income tax is the most significant motivation for management to do income smoothing. For this reason, effective tax rates are thought to be able to mediate the relationship between financial ratios and income smoothing.

The purpose of this study is to analyze both the direct and indirect effects of profitability and corporate debt on income smoothing. It also examines whether tax rates mediates. The results show that profitability and debt, as well as effective tax rates, affect income smoothing. The effective tax rates can mediate the relationship between profitability and debt and income smoothing.

\section{LITERATURE REVIEW AND HYPOTHESES DEVELOPMENT}

\subsection{Profitability}

Profitability is proxied by return on equity (ROE). The success of the company's financial performance shows the company's ability to generate profits by using its capital. The amount of ROE indicates the level of efficiency of the company in managing its capital to generate profits. Based on the description, the measure of the company's financial performance in this study is ROE. The higher ROE indicates that the company is more efficient in using its capital to generate profits or net profits (Husnan, 2001; Berger \& Di Patti, 2006).

Company's profitability is one of the factors that influences income smoothing practices. Investors often focus on this profitability before they decide to invest. If the company's profitability is high, investors will tend to invest the funds they have in the company, as they consider the company to have good ability to earn profits. Therefore, prof- itability is very important for a company. Hanafi and Halim (2016) state that profitability ratios can be used to see the company's ability to generate profits. In general, the companies that have low profitability are required to increase company profits so that the investors who have invested their capital do not move their capital to other companies. So, the management can earn profit and look more stable by making income smoothing.

ROE is one of the ratios that can be used to measure the profitability of a company. Companies with lower ROE are more likely to have a tendency to practice income smoothing compared to companies with higher ROE. This is in line with the results of the research conducted by Li-Jung and Chien-Wen (2007), which reveals that companies with lower profitability tend to do income smoothing as compared to companies with higher profitability. More fluctuations in earnings report would have a greater likelihood of occurring in companies with low profitability. Based on this, the first hypothesis to be tested in this study is:

\section{H1: Return on equity affects income smoothing.}




\subsection{Debt}

Debt is a sacrifice of future economic benefits arising from the present obligation of an entity to deliver assets or provide services to other entities in the future as a result of previous transactions. One way to measure the debt level is by using a debt to total asset ratio. Debt is proxied by debt to total asset ratio (DAR) describes the ability of a company to pay its obligations (Mashayekhi, 2005; Kasmir, 2014). The greater the DAR, the greater the risk that will be borne by investors. The high debt decreases investors' interest to invest. Companies with high DAR tend to practice income smoothing, because the company is threatened with default (Salehi, 2011). This situation cannot fulfill the obligation to repay debt on time. This is done to get a relatively good bargaining position in the negotiation or rescheduling of debts from creditors, as previously mentioned. In their research, Salehi (2011), Habib (2012) prove that debt to total assets ratio (DAR) affects on income smoothing practices. Hence, the second hypothesis to be tested in this study is:

\section{H2: Debt to total assets ratio affects income smoothing practices.}

\subsection{Effective tax rates}

Tax collection is inseparable from justice in order to create social balance for the welfare of the community. This principle of justice underlies the determination of tax rates expressed in percentages. According to Waluyo and Wirawan (2013), the tariff percentage on income tax is divided into marginal tax rates and effective tax rates. The marginal tax rate is the percentage of the applicable rate for an increase in the tax base, while the effective tax rate is the percentage of the effective tax rate that must be applied on the basis of certain tax rates. The existence of agency theory will encourage managers to increase company's profits. When the profit earned increases, then automatically the amount of income tax will increase in accordance with the increase in company's profits. Managers in agency theory will try to minimize taxes in order not to reduce manager's performance compensation (Jensen \& Smith, 2000). Companies with high profitability can pay higher taxes than companies with low profitability. The reason is that the corporate income tax will be charged based on the amount of income received. This is following Law No. 36 of 2008 , article 1 , which explains that income tax is charged to the tax subject who receives or earns income in the tax year (Law of the Republic of Indonesia, 2008). Richardson and Lanis (2007) state that companies with high profitability will pay higher taxes than companies with lower levels of profitability. Corporate companies with high profitability tend to be objects of tax audit. This is because the government intends to maximize state revenues for companies that produce large profits. Considering this proposition, the hypothesis is as follows:

\section{H3: Return on equity has a positive effect on effective tax rate.}

\subsection{Debt and effective tax rate}

Based on agency theory, debt can be used by managers to reduce corporate tax costs by utilizing debt interest costs. As it can be used as a deduction from income in taxation, it can reduce the company's tax burden. Managers choose to use debt for funding to get benefits in the form of debt interest costs. When managers can improve company's performance, managers will benefit from increased compensation (Jensen \& Smith, 2000).

The interest costs of debt arising from the existence of debt can be a tax deduction factor. Prabowo (2004) explains that loan interest, either paid and unpaid at maturity, are deductible costs of income. Derashid and Zhang (2003) explain that corporate debt harms effective tax rates illustrating that corporate debt can help reduce a company's tax burden. Therefore, if DAR is getting higher, it can comply with the effective tax rate. Based on this, the hypothesis is as follows:

\section{H4: Debt to total assets ratio has a negative effect on effective tax rate.}

\subsection{Effective tax rate and income smoothing}

Companies with low ETRs usually do have a good tax management by utilizing the existing tax facil- 
ities to pay taxes in an efficient amount. Managers tend to practice income smoothing in managing the taxation. The company continues to pay taxes to the state with an increasing amount, but not significant to avoid tax audits.

Namazi and Khansalar (2011), Al Baaj et al. (2018) state that one of the reasons for management to do income smoothing is to reduce the total tax paid by the company. The results of this study are reinforced by Habib (2012) who found that tax variables have a significant effect on income smoothing practices. Based on this, the hypothesis is as follows:

H5: Effective tax rate influences the income smoothing.

\subsection{Effective tax rate, ROE and income smoothing}

Companies with low effective tax rate (ETR) typically conduct a good tax management by utilizing the existing tax facilities to pay taxes in an efficient amount (Guenther et al., 2016). For this reason, they also tend to practice income smoothing.

The existence of agency theory will encourage managers to increase company's profits. If the profit earned increases, the amount of income tax will also increase. As agents in theoretical agencies, managers will try to minimize taxes to avoid the reduction of manager's performance compensation. It shows that the company continues to pay taxes to the state with an increasing amount, but not significant to avoid tax audits. The researches of Saedi (2012), Habib (2012) and Namazi and Khansalar (2011) state that ETR has a significant effect on the practices of income smoothing. Based on this, the hypothesis is as follows:

H6: Effective tax rate mediates the effect of return on equity on income smoothing.

\subsection{Effective tax rate, DAR and income smoothing}

Companies with low ETRs usually do good tax management by exploiting the existing tax facil- ities to pay taxes in a certain amount. Based on agency theory, debt can be used by managers to reduce corporate tax costs by utilizing debt interest costs. As it can be used as a deduction from income in taxation, it can reduce the company's tax burden. Managers choose to use debt for funding to get a profit in the form of debt interest costs. When managers can improve company's performance, managers will benefit from an increased compensation.

The results of the study by Habib (2012), Namazi and Khansalar (2011), Delgado et al. (2012) showed that ETR had a significant influence on the practice of income smoothing. Based on this, the hypothesis is as follows:

H7: Effective tax rate mediates the influence of debt to total assets ratio on income smoothing.

\section{RESEARCH METHODS}

\subsection{Population and sample}

The population in this study were 49 property and real estate companies listed on the Indonesia Stock Exchange from 2013 to 2017. The sample in this study was taken by purposive sampling method, which is the determination of samples based on the suitability of certain characteristics and criteria (Ghozali, 2015). The research sample totalled to 12 companies with a number observation of 60 . This study used the Structural Equation Model (SEM) approach with Partial Least Squares (PLS) software, WarpPLS software version 6.0. PLS is a variants-based SEM method.

\subsection{Variable measurements}

The income smoothing value is calculated using the Eckel index (1981). The Eckel index uses Coefficient Variation $(\mathrm{CV})$ variable profit and net sales that can be calculated using the following formula:

$$
\text { Income smoothing index }=\frac{C V \Delta I}{C V \Delta S},
$$

$C V \Delta I$ and $C V \Delta S=\sqrt{\text { Variance }} /$ Expected value, 
where $\Delta I$ - changes in earnings within a period, $\Delta S$ - variation coefficients of variables, namely standard deviations divided by the expected value. If:

- $\quad C V \Delta I>C V \Delta S$, then the company is not classified as doing income smoothing;

- $\quad C V \Delta I<C V \Delta S$, then the company is classified as doing income smoothing.

\section{Return on equity (ROE)}

Company's profitability is measured by using the return on equity (ROE) ratio, which is a ratio that shows what percentage of net income is obtained when measured by the owner's capital. The scale of the ratio is scale measurement as suggested by Kasmir (2014) as follows:

$$
\text { Return on equity }=\frac{\text { Net income after tax }}{\text { Total equity }} .
$$

\section{Debt to total asset ratio (DAR)}

According to Kasmir (2014), company's leverage is measured using the debt to total assets ratio (DAR). It is a ratio that calculates how much of the total assets of a company is financed by total debt.

\subsection{Effective tax rates}

Richardson and Lanis (2007) describe effective tax rates as a comparison between taxes paid in that year and earning before taxes. Effective tax rates are calculated using the following formula:

$$
\text { Effective tax rates }=\frac{\text { Current tax }}{E B T} \cdot 100 \% \text {. }
$$

\section{RESULTS AND DISCUSSION}

\subsection{Results of the measurement model (outer model) evaluation}

Formative indicators are used to test the outer model for observed data. Evaluation of formative indicators is done by looking at the weight indicator. The results of the outer model evaluation on formative indicators can be seen in Table 1 .

Table 1 shows that there is no variable indicator that has a VIF value above 3.3 and a $p$-value $<0.05$ for all indicators. Therefore, it can be concluded that the formative data in the study are feasible to be tested.

\subsection{Model fit index}

The fit model can be evaluated by determining the number of fit indicators whose results can be seen in Table 2.

It can be seen from Table 2 that the average path coefficient (APC) value is 0.258 with $p$-value $=0.008$, Average R-Squared (ARS) is $0.170, p$-value $=0.042$, Average Adjusted R-Squared (AARS) is $0.133, p$-value $=0.071$. The Average Adjusted R-Squared (AARS)

\begin{tabular}{|c|c|c|c|c|c|c|c|c|}
\hline Indicators & IS & TPE & ROE & DAR & Type & SE & $p$-value & VIF \\
\hline IS & 1.000 & 0.000 & 0.000 & 0.000 & Formative & 0.091 & $<0.001$ & 0.000 \\
\hline TPE & 0.000 & 1.000 & 0.000 & 0.000 & Formative & 0.091 & $<0.001$ & 0.000 \\
\hline ROE & 0.000 & 0.000 & 1.000 & 0.000 & Formative & 0.091 & $<0.001$ & 0.000 \\
\hline DAR & 0.000 & 0.000 & 0.000 & 1.000 & Formative & 0.091 & $<0.001$ & 0.000 \\
\hline
\end{tabular}

Table 1. Results of weight indicator evaluation

Note: Significance at VIF $>3.3$, p-value $<5 \%$, respectively.

\begin{tabular}{|c|c|c|c|c|}
\hline No. & Model fit and quality indices & Fit criteria & Analysis results & Description \\
\hline 1 & Average path coefficient (APC) & $p<0.05$ & $0.258(p=0.008)$ & Good \\
\hline 2 & Average R-Squared (ARS) & $p<0.05$ & $0.170(p=0.042)$ & Good \\
\hline 3 & Average Adjusted R-Squared (AARS) & $p<0.05$ & $0.133(p=0.071)$ & Good \\
\hline 4 & Average Block Variance Inflation Factor (AVIF) & Acceptable if $<=5$, ideally $<=3.3$ & 1.029 & Ideal \\
\hline 5 & Average Full Collinearity VIF (AFVIF) & Acceptable if $<=5$, ideally $<=3.3$ & 1.120 & Ideal \\
\hline 6 & Tenenhaus GoF (GoF) & Small $>=0.1$, medium $>=0.25$, large $>=0.36$ & 0.413 & Large \\
\hline
\end{tabular}

Table 2. Test results of model fit index

Note: Significance at fit criteria, respectively. 
value has a $p$-value above 0.05 . This means that the model in this study does not meet the fit index model.

Table 2 also shows that the Average Block Variance Inflation Factor (AVIF) value is 1.029 and Average Full Collinearity VIF (AFVIF) is $1.120<3.3$. This can be interpreted that there is no problem of multicollate between indicators and exogenous variables.

Furthermore, Figure 1 also shows that the Tenenhaus value of goodness of fit $(\mathrm{GoF})$ is $0.413>0.36$. This shows that the predictive power of the model is large. Tenenhaus goodness of fit $(\mathrm{GoF})$ calculation results show that the measurement model (computer model) and structural model (inner model) is correct, because it has a value of 0.413 (above 0.36 ). This means that the research model is correct and feasible to use.

\subsection{Hypotheses testing results}

The following are the results of the evaluation of structural models and the direct effect of exogenous variables on endogenous variables.
It can be seen from Table 3 that return on equity has an effect on income smoothing with coefficient value of 0.24 and $p$-value $0.03<0.05$. Debt to total assets ratio has an effect on income smoothing with coefficient value of 0.20 and $p$-value $0.04<0.05$. Return on equity affects effective tax rate with coefficient value of -0.40 and $p$-value $0.01<0.05$. Debt to total assets ratio affects effective tax rate with coefficient value of 0.21 and $p$-value $0.04<0.05$. Effective tax rate has an effect on income smoothing with coefficient value of 0.23 and $p$-value $0.03<0.05$. This means ROE, and DAR, affect income smoothing and effective tax rates. Effective tax rate has an effect on income smoothing.

It can be seen from Table 4 that return on equity affects income smoothing with coefficient value of 0.24 and $p$-value $0.03<0.05$. Return on equity affects effective tax rate with coefficient value of -0.40 and $p$-value $0.01<0.05$. Effective tax rate has an effect on income smoothing with coefficient value of 0.23 and $p$-value of $0.03<0.05$.

This means ROE affects income smoothing and effective tax rate. Effective tax rate have an effect on income smoothing.

Table 3. Hypotheses testing results of direct effects

\begin{tabular}{|c|c|c|c|}
\hline \multirow{2}{*}{ Relationship of variables } & \multicolumn{2}{|c|}{ Direct effect } & \multirow{2}{*}{ Hypotheses } \\
\hline & Coef. & $p$-value & \\
\hline Return on equity (ROE) $\rightarrow$ Income smoothing & 0.24 & 0.03 & H1 Significant \\
\hline Debt to total assets ratio (DAR) $\rightarrow$ Income smoothing & 0.20 & 0.04 & H2 Significant \\
\hline Return on equity (ROE) $\rightarrow$ Effective tax rates & -0.40 & $<0.01$ & H3 Significant \\
\hline Debt to total assets ratio (DAR) $\rightarrow$ Effective tax rates & 0.21 & 0.04 & H4 Significant \\
\hline Effective tax rates $\rightarrow$ Income smoothing & 0.23 & 0.03 & H5 Significant \\
\hline
\end{tabular}

Note: Significance at $5 \%$, respectively.

Table 4. Hypotheses testing results of indirect effects

\begin{tabular}{|c|c|c|c|}
\hline \multirow{2}{*}{ Relationship of variables } & \multicolumn{2}{|c|}{ Direct effect } & \multirow{2}{*}{ Hypotheses } \\
\hline & Coef. & $p$-value & \\
\hline Return on equity $(R O E) \rightarrow$ Income smoothing & 0.24 & 0.03 & H1 Significant \\
\hline Return on equity (ROE) $\rightarrow$ Effective tax rates & -0.40 & $<0.01$ & H3 Significant \\
\hline Effective tax rates $\rightarrow$ Income smoothing & 0.23 & 0.03 & H6 Significant \\
\hline
\end{tabular}

Note: Significance at $5 \%$, respectively.

Table 5. Hypotheses testing results of indirect effects

\begin{tabular}{|c|c|c|c|}
\hline \multirow{2}{*}{ Relationship of variables } & \multicolumn{2}{|c|}{ Direct effect } & \multirow{2}{*}{ Hypotheses } \\
\hline & Coef. & $p$-value & \\
\hline Debt to total assets (DAR) $\rightarrow$ Income smoothing & 0.20 & 0.04 & H2 Significant \\
\hline Debt to total assets (DAR) $\rightarrow$ Effective tax rates & 0.21 & 0.04 & H4 Significant \\
\hline Effective tax rates $\rightarrow$ Income smoothing & 0.23 & 0.03 & H7 Significant \\
\hline
\end{tabular}

Note: Significance at $5 \%$, respectively. 


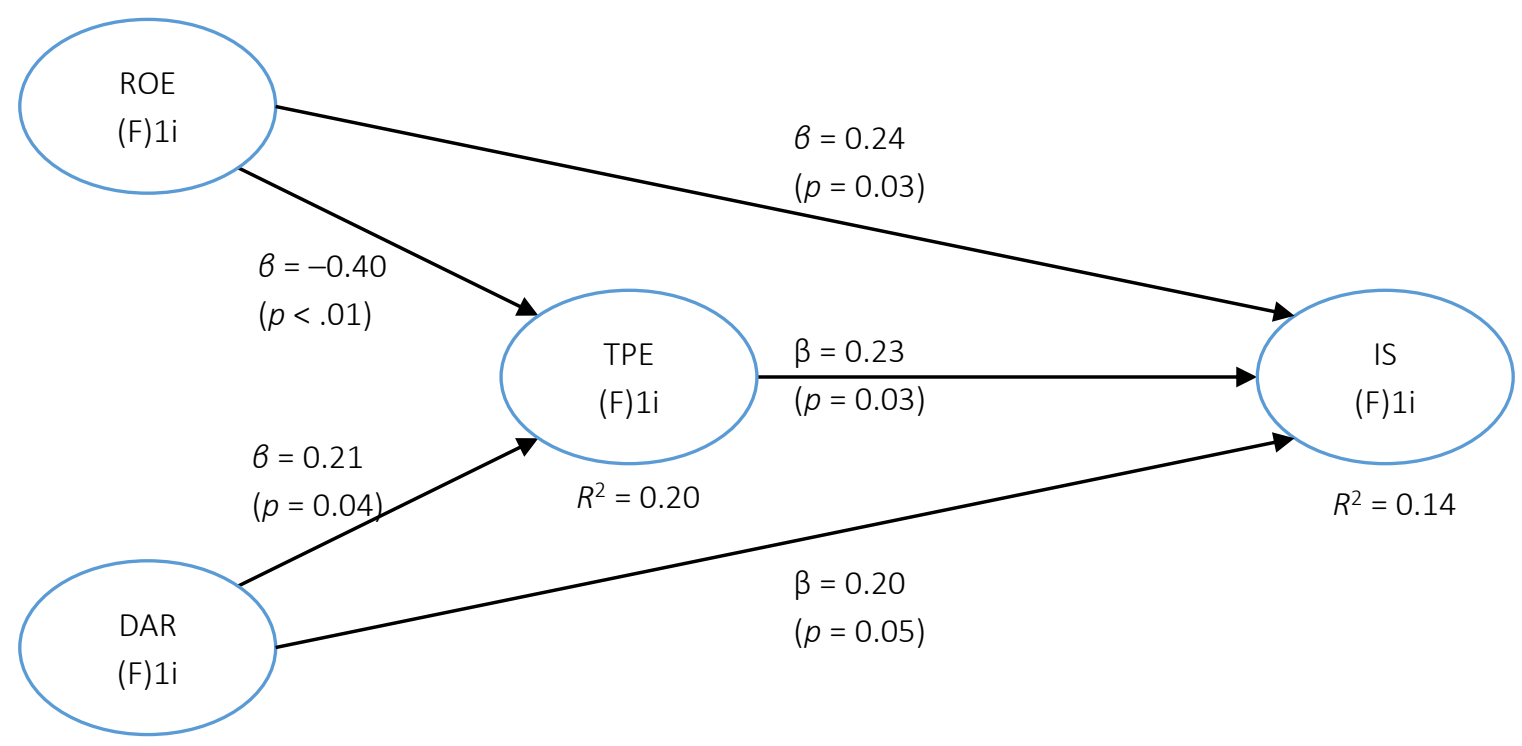

Figure 1. Results of PLS analysis

It can be seen from Table 5 that debt to total asset has an effect on income smoothing with coefficient value of 0.20 and $p$-value $0.04<0.05$. Debt to total assets have an effect on effective tax rate with coefficient value of 0.21 and $p$-value $0.04<0.05$. The effective tax rate affects income smoothing with coefficient value of 0.23 and $p$-value of $0.03<0.05$. This means that DAR has an effect on income smoothing and effective tax rate. Effective tax rate affect income smoothing. In brief, the results of WarpPLS analysis are shown in Figure 1.

\section{DISCUSSION}

Return on equity affect income smoothing. Investors often focus their attention on the profitability of the companies that they will target for investments. If the profitability of the company is good, investors will tend to invest the funds they have in the company. They will assume the company with good profitability will have good ability to earn profits. Therefore, profitability is very essential element to the company. This shows that the higher the return on equity of a company, most likely the company tends to practice income smoothing. This is because the management wants to show investors that the profits generated by the company will always be stable. The companies with high Return on Equity tend to practice income smoothing. Klein et al. (2005) state that profitability is an important measure to assess the health or failure of a company that influences the investors to make decisions. The company's profitability is indeed one of the factors that influence the income smoothing. Positive accounting theory states that a bonus plan is one factor that could encourage management to do income smoothing. This happens because bonus plans are often associated with opportunities for managers to enjoy a share of profits. If the company is able to produce a certain level of profit that has been targeted, the management will get a bonus from its company (Moradi, 2015). This can further trigger management to do income smoothing so that the bonus they get always increased every year. Habib (2012), Acharya and Lambrecht (2015) and Fengju et al. (2013) state that Return on Equity is positively related to income smoothing. Return on equity (ROE) has a negative effect on effective tax rate (ETR). ETR is the amount of real rates paid by the company. Companies with high level of profitability can pay lower taxes than companies with low profitability. The reason is because managers try to carry out tax management by utilizing the existing tax facilities to be able to streamline tax payments so that companies can pay less tax. Richardson and Lanis (2007) also argue that higher ROE indicates that the company has good resources, so that it encourages the companies to carry out tax management. This action can reduce the effective tax rate. Andrea and Georgeta (2013) state that high ROE shows that companies have good resources that can encourage compa- 
nies to perform good tax management. This can reduce effective tax rates. It can be concluded that companies with high profitability usually have good human resources and understand tax regulations well. Thus, they can carry out tax management properly, which results in effective tax rates. Richardson and Lanis (2007) report that ROE is negatively related to effective tax rates.

Debt to total assets ratio (DAR) has a positive effect on income smoothing. DAR is a large amount of debt compared to the amount of assets owned by the company. This can encourage companies to do income smoothing. This is following the debt contract hypothesis, which encourages the emergence of income smoothing phenomena in positive accounting theory, where one of the causes of management doing income smoothing is the debt contract hypothesis. Thus, the higher the level of DAR owned by the company, the greater the tendency of management to do income smoothing. Companies with high DAR tend to do income smoothing, because the companies are threatened with default, which is not able to fulfill the obligation to pay the debts on time. This is done to get a relatively good bargaining position in negotiations or debt rescheduling from the creditors. The management is trying to done an income smoothing so that its performance looks good. In theory, debt contracts can encourage management to practice income smoothing. This is because by doing income smoothing, the management can show the creditor that the company is in favorable condition and can make debt payments along with the interest. Habib (2012) states that higher DAR will encourage the companies to do income smoothing, because it can reduce the cost of violating the debt agreement and impress the debt owner that the company can still maintain revenue flows for itself. Studies by Salehi (2011), and Habib (2012) prove that debt to total assets ratio (DAR) has a positive effect on income smoothing.

Debt to total assets ratio (DAR) has a positive effect on effective tax rate (ETR). In agency theory, debt can be used by managers to reduce corporate tax costs by utilizing debt interest costs. This is possible because the interest cost of debt can be used as a deduction from income in taxation so that it can reduce the company's tax burden. Derashid and Zhang (2003) state that the company's debt can help to reduce the company's tax charge. Due to the interest charge that derived from the debt, it can be used as a charge in calculating taxes so that it can reduce the effective tax rate.

The management makes use of the interest costs incurred on debt in carrying out its tax management. This is because a large interest expense can affect company's profits, making company managers use debt to carry out tax management to maximize company's profits. This can also be caused by the average effective tax rates on property and real estate listed on the Indonesia Stock Exchange (IDX) from 2013 to 2017. It was only at $5.10 \%$ or far below the tax rate set by the tax law (by 25\%). This happens probably due to the many activities of the company subject to final tax. By using interest expense as tax deduction, therefore, management can reduce effective tax rates.

Effective tax rates (ETR) affect income smoothing. This happens because managers intend to pay minimum taxes. The management's desire is always to pay low taxes, which is one of the factors that encourages management to do income smoothing.

Companies with low ETRs usually do good tax management by utilizing the existing tax facilities to pay taxes in an efficient amount. The results of this study are in line with agency theory. As an agent, the manager will try to minimize taxes so as not to reduce the manager's performance compensation. This tax management then encourages management to practice income smoothing in achieving these objectives. Namazi and Khansalar (2011) argue that one of the reasons for management for doing income smoothing is to reduce the total tax paid by the company. This is in line with the research of Namazi and Khansalar (2011), which proves that the effective tax rate (ETR) affects the practice of income smoothing. The results of these studies are reinforced by Delgado (2012), Habib (2012) who revealed that tax variables have a significant influence on the practice of income smoothing.

Effective tax rates (ETR) can mediate the effect of return on equity (ROE) on income smoothing. This means that ROE has an effect on ETR and simultaneously ETR has an impact on income smoothing. ROE is one measure to assess the health or failure of a company. The higher return 
on equity (ROE) of a company, the more profitable it will be for investors to invest in the company. This is because in agency theory, managers will increase company's profits. When the profit earned increases, the amount of income tax will increase in accordance with the increase in company's profits. Companies with high profitability can pay lower taxes than companies with low profitability. The reason is that the managers try to conduct tax management by utilizing the existing tax facilities so that they can make the tax payments efficient, then the companies only have the obligation pay a little tax.

As agents in the agency theory, managers will try to minimize taxes so as not to reduce compensation for the manager's performance as a result of reduced corporate profits by the tax burden. In this way, companies with high profitability can pay lower taxes than companies that have low profitability. Managers strive to carry out tax management by utilizing the existing tax facilities so as to streamline payment of corporate taxes. This is in line with Saedi (2012) who found a negative relationship between return on equity (ROE) and effective tax rates. Furthermore, companies with low ETRs usually conduct good tax management by utilizing the existing tax facilities to pay taxes in an efficient amount. Managers tend to carry out income smoothing practices in managing taxation to show that companies continue to pay taxes to the state with increasing but not signif- icant amounts to avoid tax audits. Habib (2012) and Namazi and Khansalar (2011) state that effective tax rates have a significant influence on the practice of income smoothing.

DAR can affect effective tax rates in a company. This can be caused by the management using debt. This is because the use of debt is considered to earn interest, which will reduce the company's profits. Companies with high tax payment tend to do income smoothing. Management uses debt to make effective tax rate. Companies with low ETRs usually carru out good tax management by utilizing the existing tax facilities to pay taxes in an efficient amount. Therefore, companies tend to practice income smoothing in managing the taxation. The company continues to pay taxes to the state with an increasing but not significant amount to avoid tax audits.

High effective tax rates encourage companies to do income smoothing. This is because companies have been subjected to large taxes by the government. Tax is a charge that must be certified by the company, which results in a reduction of the company profits. So, the companies that have high tax rates try to show that the companies can still obtain profits by doing income smoothing. This is done so that external parties still see the companies in good condition and the companies continue to generate stable profits despite having a large effective tax rate. Habib (2012), Namazi and Khansalar (2011) reveal that tax variables have a significant influence on the practice of income smoothing.

\section{CONCLUSION}

This study aims to analyze both direct and indirect effect of profitability and corporate debt on income smoothing. Effective tax rates can mediate the effect of profitability and debt on income smoothing. The tests were performed on the sample of 12 companies in the sectors of property and real estate in the Indonesia Stock Exchange. Sixty observations were done during 2013-2017. The results were obtained by using Partial Least Squares (PLS) analysis tool with the WarpPLS application. The results show that profitability and debt, as well as effective tax rates, affect income smoothing. The effective tax rates mediate the relationship between profitability and debt and income smoothing.

Two limitations emerge and are worth noting. First, the sample in this study was only focused on property and real estate companies, thus, the results of the study are specific. Second, this study only used one type of effective tax rates out of several tax rates that are applicable in Indonesia. 


\section{SUGGESTIONS AND FUTURE RESEARCH}

From the results, investors are expected to pay more attention to the comparison of profitability with corporate debt before investing, because a large debt will reduce ETR. The sample in this study only focused on property and real estate companies. Therefore, further research could use samples from other sectors from the Indonesia Stock Exchange. Further research can be done in other sectors on the Indonesia Stock Exchange to get predictions and pattern of income smoothing done by management, using inventory intensity and risk management.

\section{REFERENCES}

1. Acharya, V. V., \& Lambrecht, B. M. (2015). A theory of income smoothing when insiders know more than outsiders. The Review of Financial Studies, 28(9), 2534-2574. https://doi.org/10.1093/rfs/hhv026

2. Al Baaj, Q. M. A., Alzabari, S. A. H. Al., \& Marshedi, A. A. S. (2018). The Impact of Income Smoothing on Tax Profit: An Applied Study To A Sample of International Companies. Academy of Accounting and Financial Studies Journal, 22(5), 1-11. Retrieved from https://www.abacademies. org/journals/month-october-year2018-vol-22-issue-5-journal-aafsjpast-issue.html

3. Andreea, A. C., \& Georgita, V. (2013). The Analysis of Correlation Between Profit Tax and Corporate Financial Performance. Academic of Economic Master DAFI (Financial Management and Stock Exchange). ASE Bucharest, 6, 1-12.

4. Ball, R., Kothari, S.P., \& Robin, A. (2000). The effect of international institutional factors on properties of accounting earnings. Journal of accounting and economics, 29(1), 1-51. https://doi.org/10.1016/ S0165-4101(00)00012-4

5. Banam, M., \& Mehzaren, A. (2016). The Relationship of Information Asymmetry, Institutional Ownership and Stock Liquidity with Income Smoothing in Tehran Stock Exchange. UCT Journal of Management and Accounting Studies, 4(3), 10-15. Retrieved from https://www.tpbin. com/journal-article/01122

6. Berger, A. N., \& Di Patti, E. B. (2006). Capital structure and firm performance: A new approach to testing agency theory and an application to the banking industry. Journal of Banking \& Finance, 30(4), 1065-1102. https://doi.org/10.1016/j.jbankfin.2005.05.015

7. Delgado, F., Fernández-Rodríguez, E., \& Martínez-Arias, A. (2012). Size and other Determinants of Corporate Effective Tax Rates in US Listed Companies. International Research Journal of Finance and Economics, 98, 160-165. Retrieved from https://www.researchgate.net/ publication/258448239_Size_ and_other_determinants_of_ corporate_effective_tax_rates_in_ US_listed_companies

8. Derashid, C., \& Zhang, H. (2003). Effective Tax Rates and The Industrial Policy Hypothesis: Evidence from Malaysia. Journal of International Accounting, Auditing and Taxation, 12(1), 4562. https://doi.org/10.1016/S10619518(03)00003-X

9. Eckel, N. (1981). The Income Smoothing Hypotesis Revisited. Abacus, 17(1), 28-40. https://doi. org/10.1111/j.1467-6281.1981. tb00099.x

10. Fengju, X. R., Fard, Y., Maher, L. G., \& Akhteghan, N. (2013). The Relationship Between Financial Leverage and Profitability with an Emphasis on Income Smoothing in Iran's Capital Market. European Online Journal of Natural And Social Sciences, 2(3), 156-164. Retrieved from http://europeanscience.com/eojnss/article/ view/355

11. Frey, L. (2018). Tax Certified Individual Auditors and Effective
Tax Rates. Business Research, 11(1), 77-114. https://doi.org/10.1007/ s40685-017-0057-8

12. Ghaemi, M. H., Gheytas Vand, M., \& Vatujaki, M. (2003). Income Smoothing Effect on Return of Tehran Stock Exchange Listed Companies. Review of Accounting and Auditing, 1(33), 131-150.

13. Ghozali, I., \& Hengky, L. (2015). Concept, Technique, The Application Uses Smart PLS 3.0 for Empirical Research. Semarang: University of Diponegoro Press.

14. Guenther, D. A., Matsunaga, S. R., \& Williams, B. M. (2016). Is tax avoidance related to firm risk? The Accounting Review, 92(1), 115-136. https://doi.org/10.2308/ accr-51408

15. Habib, A. (2012). Managerial ownership-induced income smoothing and information asymmetry. Pacific Accounting Review, 24(2), 211-232. https://doi. org/10.1108/01140581211259839

16. Hanafi, M. M., \& Abdul, H. (2016). Analysis of Financial Statement (5th ed.). Yogyakarta: UPP STIM YKPN Publisher.

17. Husnan, S. (2001). Financial Management Theory and Tthe Application of Short Term Decision (4th ed.). Yogyakarta: BPFE Publisher.

18. Jackson, S. B., \& Pitman, M. K. (2001). Auditors and earnings management. The CPA journal, 71(7), 38. Retrieved from http://archives.cpajournal.com/2001/0700/ features/f073801.htm

19. Jensen, M. C., \& Smith, C. W. (2000). Stockholder, Manager, and 
Creditor Interests: Applications of Agency Theory. Theory of the Firm (Book), 1(1). http://dx.doi. org/10.2139/ssrn.173461

20. Kasmir. (2014). Analysis Financial Statement (1st ed.). Jakarta: PT Raja Grafindo Persada Publisher.

21. Klein, P., Shapiro, D., \& Young, J. (2005). Corporate Governance, Family Ownership and Firm Value: the Canadian Evidence. Corporate Governance An International Review, 13(6), 769-784. https://doi.org/10.1111/ j.1467-8683.2005.00469.x

22. Law of the Republic of Indonesia. (2008). Retrieved from https:// www.expat.or.id/info/2008-IncomeTaxSDSN-Amendment.pdf

23. Li, S., \& Richie, N. (2016). Income smoothing and the cost of debt. China Journal of Accounting Research, 9(3), 175-190. https:// doi.org/10.1016/j.cjar.2016.03.001

24. Li-Jung, T., \& Lai, C-W. (2007). Relationship Between Income Smoothing and Company Profitability: an Empirical Study. International journal of management, 24(4), 727-733. Retrieved from https://search. proquest.com/openview/348a855 815ee27c8d32e818d7a44c03d/1? pq-origsite $=$ gscholar $\& \mathrm{cbl}=5703$
25. Mashayekhi, B. (2005). Discretionary Accruals Roles in Profit Smoothing of Tehran Stock Exchange. Review of Accounting and Auditing, 12(42), 74-61.

26. Moradi, M. (2015). Analysis of Incentive Effect of Manager's Bonuses on Real Activities Manipulation Relevant to Future Operating Performance. Management Decision, 53(2), 432450. https://doi.org/10.1108/MD04-2014-0172

27. Namazi, M., \& Khansalar, E. (2011). An Investigation of the Income Smoothing Behavior of Growth and Value Firms (Case Study: Tehran Stock Exchange Market). International Business Research, 4, 84-94. https://doi. org/10.5539/ibr.v4n4p84

28. Prabowo, Y. (2004). Applied Tax Accounting. Jakarta: Gramedia Widiasarana Indonesia Publisher.

29. Richardson, G., \& Lanis, R. (2007). Determinants of Variability in Corporate Effective Tax Rates and Tax Reform: Evidence from Australia. Journal of Accounting and Public Policy, 26(6), 689-704. https://doi.org/10.1016/j.jaccpubpol.2007.10.003

30. Saedi, P. (2012). The Relationship Beetween Income Smoothing and Income Tax and Profitability
Ratios in Iran Stock Market. Asian Journal of Finance \& Accounting, 4, 46-51. https://doi.org/10.5296/ajfa. v4i1.790

31. Salehi, M., \& Manesh, N. B. (2011). The Effect of Income Smoothing on the Informativeness of Stock Price. Asian Journal on Quality, 12, 80-90. https://doi. org/10.1108/15982681111140561

32. Scott, W. R. (2011). Financial Accounting Theory (6th ed.). Canada: Person Prentice Hall.

33. Syahrul, Y. (2002). Bapepam: Kimia Farma Cases. Retrieved from http://www.tempo.co/read/ news/2002/11/04/05633339/Bapepam-Kasus-Kimia-Farma-Merupakan-Tindak-Pidana (accessed on November 4, 2002).

34. Waluyo, \& Wirawan, B. I. (2013). Indonesian Taxation. Jakarta: Salemba Empat Publisher.

35. We Fu, T., Chu Ke, M., \& Sheng Huang, Y. (2002). Capital Growth, Financing Source and Profitability of Small Businesses: Evidence from Taiwan. Small Enterprises, Small Business Economic, 18, 257-267.

36. Zeng, T. (2010). Income tax liability for large corporations in China: 1998-2007. Asian Review of Accounting, 18(3), 180-196. https://doi. org/10.1108/13217341011089612 